\title{
Long-Term Variation of Sunshine Duration and Their Inter-Action with Meteorogical Parameters over Chad, Central Africa
}

\author{
Saka Goni1,2*, Haroun Ali Adannou, 1,3, Dialo Diop1, Mamadou S. Drame1, \\ Bienzeube Tikri², Mahamat Barka4 ${ }^{4}$, Aboubaker Cheidikh Beye ${ }^{1}$
}

${ }^{1}$ Groupe de Laboratoire de Physique des Solides et Sciences des Matériaux, Faculté des Sciences et Techniques, Université Cheikh Anta Diop de Dakar, Dakar, Sénégal

${ }^{2}$ Département de Génie Industriel et Maintenance, Université Polytechnique de Mongo, Mongo, Tchad

${ }^{3}$ Département Génie Chimique, Institut National Supérieur de Pétrole de Mao, Mao, Tchad

${ }^{4}$ Faculté des Sciences Exactes et Appliquées, Université de Ndjamena, Ndjamena, Tchad

Email: *saka_goni@yahoo.fr

How to cite this paper: Goni, S., Adannou, H.A., Diop, D., Drame, M.S., Tikri, B., Barka, M. and Beye, A.C. (2019) Long-Term Variation of Sunshine Duration and Their Inter-Action with Meteorogical Parameters over Chad, Central Africa. Natural Resources, 10, 47-58.

https://doi.org/10.4236/nr.2019.103004

Received: February 2, 2019

Accepted: March 16, 2019

Published: March 19, 2019

Copyright (c) 2019 by author(s) and Scientific Research Publishing Inc. This work is licensed under the Creative Commons Attribution International License (CC BY 4.0).

http://creativecommons.org/licenses/by/4.0/

\begin{abstract}
This study aims to evaluate the long-term variations of sunshine duration and to estimate its interaction with meteorogical parameters from 1950 to 2010 in Chad, Central Africa. The results show that Chad is the one of world's sunniest countries. Each year, Chad receives more than $3030.91 \pm 176.33$ hours of sunning corresponding to 8.9 hours daily. Likewise, a strong north-south gradient is noted over Chad. For instance, the daily insolation is $10 \pm 0.41$ hours in the north, 8.85 \pm 1.1 hours in the center and $7.75 \pm 1.8$ hours in the south. Furthermore, there is a marked seasonality of sunshine duration with maximums in dry season and minimums during the rainy season. The lowest values of sunshine duration are found in August. On the contrary, maximums are recorded from November to February with values greater than 9.5 hours per day. Moreover, the annual anomalies study allowed determining three great periods in terms of sunshine variability in Chad. Firstly, the period between 1950 to 1970 (named humid period) is characterized by the lowest values of sunshine duration in Chad. Secondly, from 1970 and 1990, the region suffered an unprecedented drought which resulted in an increase of sunstroke duration in Chad. And finally, the period from 1990 to 2010 called the return period is characterized by a rapid year-to-year fluctuations of insolation duration. Unlike to surface temperature, we have also shown that there is a direct relation between the duration of insolation and the meteorological parameters such as precipitations and relative humidity.
\end{abstract}

\section{Keywords}

Sunshine Duration, Solar Energy, Climate, Variability, Chad, Central Africa 


\section{Introduction}

Sunshine is a key factor in most climate processes e.g. Earth's radiative balance and hydrological cycle (Ranzi et Rosso, 1995) [1]. The sunshine hour is the most important influencing parameter of evapotranspiration process (Pandey et al. 2014, 2016) [2] [3]. Thus, Sunshine duration variations can disrupt the hydrological cycle by reducing evaporation, resulting in reduced precipitation and agricultural yields in some areas. Overall, Sunshine duration has been used for decades in many different applications. It is applied in sectors such as tourism, public health, agriculture, vegetation and solar energy (Murthy et al., 2011; Wang et al., 2013; Wang et al., 2015; Babikir et al., 2018) [4] [5] [6] [7]. Besides with the dramatic global climate change in recent years, there has been a great deal of interest in varying the duration of sunshine (Yang et al. 2009; Lenuta et al. 2014) [8] [9]. For instance, the duration of sunshine decreased in the Northern and Eastern Austria in the 30-year period of 1960-1989 while a remarkable increase in sunshine duration was observed in high mountain regions (Dobesch, 1992) [10]. In Western Europe, the annual sunshine duration showed an overall decrease since the 1950s until the early 1980s, followed by a recovery during the next two decades (Sanchez-Lorenzo et al., 2008) [11]. However, few studies have been published on sunshine duration in Africa despite its good solar potential (Babikir et al., 2018) [7]. Indeed, the sunshine duration has a fairly direct relationship with the solar radiation received at the surface. Consequently, the knowledge of the Sunshine variability represents a determining factor for design, dimensioning, performance assessment, and energetic management of renewable energy conversion systems for countries devoid of solar radiation measurement. The focus of this work is on a Chad, country located between Sahel and Central Africa. Its climate is characterized by warm and dry continental type. From north to south of Chad, we have a succession of Saharan climate in the north, Sahelian in center and Sudanese in the South (Bedoum et al., 2013, Maharana et al., 2018) [12] [13]. As most Sahelian countries, Chad endured an intense drought from the early 1970s to the late 1980s. This drought has been manifested by a rainfall deficit that has had a negative impact on the region agriculture and economy (Lebel et al., 1996; Lebel and Ali, 2009; Nicholson, 1998; Nicholson et al., 2000; Bigot et al., 1998; Mahe et al., 2001; Malhy et Wright, 2004; Guenang et Mkankam Kamga., 2012; Bedoum et al., 2013, Redelsperger et al., 2002) [14]-[23]. One of the major questions is to know if the recently flucatuations of Africa climate (great drought of the 70s and recently global climate change) have had an impact on sunshine duration. The aim of this work is to study the long-term variability of sunshine duration and its interaction with climatic parameters in Chad, Central Africa. The paper is organized as follows. "Data and Methodology" presents the study area (the map of Chad with her 7 ground stations), the datasets used in this work and the methodology. The results are presented in "Results and discussions". 


\section{Data and Methodology}

\subsection{Study Area Presentation}

Figure 1 represents our study area which is Chad, a country located between the Sahel and Central Africa; and having an area of 1,284,000 $\mathrm{km}^{2}$. It's situated from $7^{\circ} \mathrm{N}$ and $24^{\circ} \mathrm{N}$ north latitude; and between $14^{\circ} \mathrm{E}$ and $24^{\circ} \mathrm{E}$ longitude. Furthermore, this country spread over the length of $1700 \mathrm{~km}$ from North to South and $1000 \mathrm{~km}$ from East to West. Chad is the fifth largest country in Africa after Algeria, the Democratic Republic of Congo, Sudan and Libya and the $21^{\text {st }}$ largest in the world. For this study, seven stations measuring the insolation duration over Chad (Figure 1) were used. In the north of the country, we have the FayaLargeau station (long $19^{\circ} 07$, Lat $17^{\circ} 55$, Alt 233). The center region has 3 stations composed of the stations of Abéché (long $20^{\circ} 51$, Lat $13^{\circ} 51$, Alt 545) of N'Djamena (long $15^{\circ} 02$, Lat $12^{\circ} 08$, Alt 294) and Amti-man (long 20 17 , Lat $11^{\circ} 02$, Alt 435). And finally, the 3 stations of the south of the country are those of Moundou (long $16^{\circ} 04$, Lat $8^{\circ} 02$, Alt 420), Sarh (long $18^{\circ} 22$, Lat $9^{\circ} 00$ Alt 300) and Pala (Long $14^{\circ} 55$, Lat $9^{\circ} 22$, Alt 454 ).

\subsection{Datasets Collection}

In this study, in situ data of sunshine duration, precipitation, humidity, Temperature (Average, Maximum and Minimum), for the 1950-2010 period (60 years) have been collected from the General Directorate of Meteorology (GDM) of Chad. For each of 7 ground stations (see Figure 1), daily insolation measurements (at sunrise and at sunset) are carried out using a Campbell-Stokes heliograph while the others parameters are measured by conventional weather station.

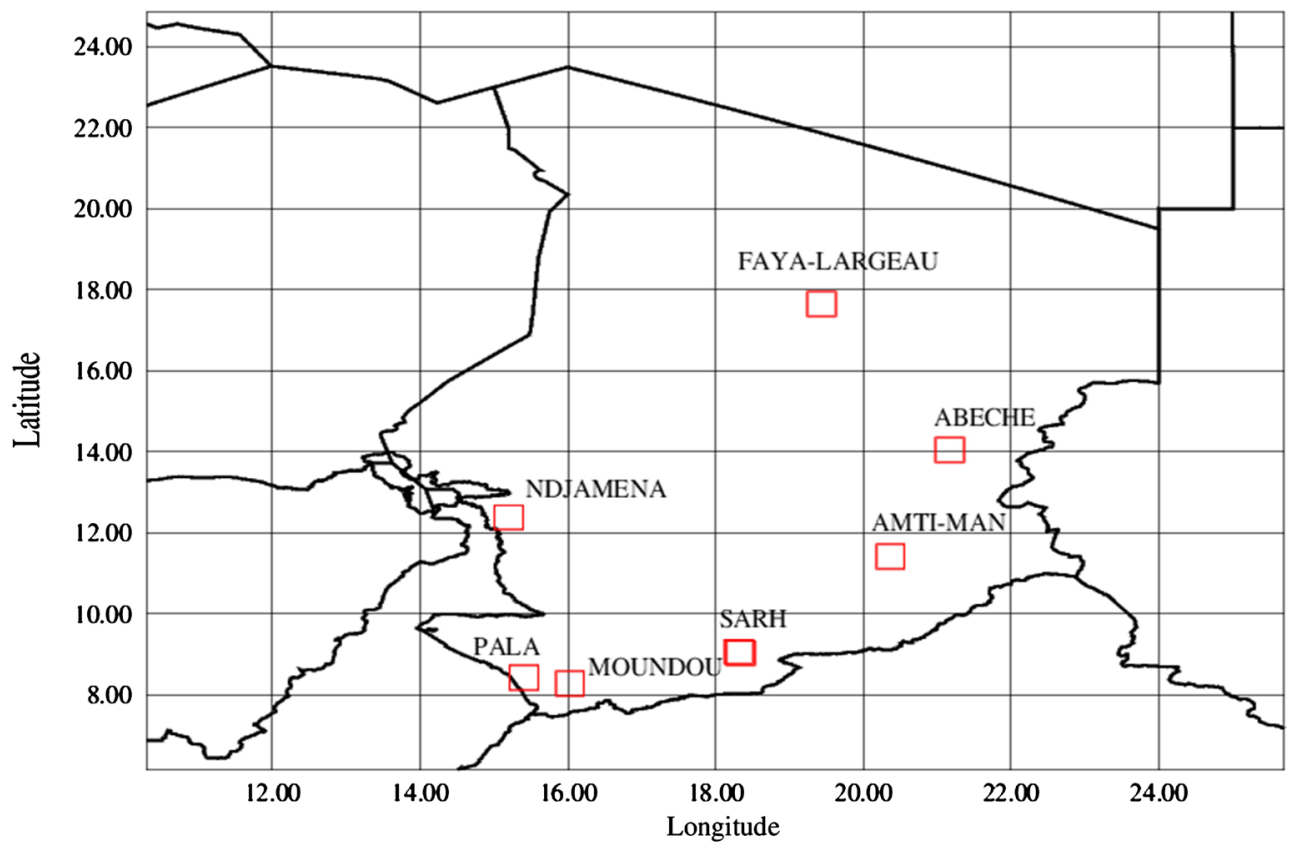

Figure 1. Map of Chad with the seven (07) stations measuring the duration of insolation which are: Faya, Abeche and Moundou. 
The usefulness of this system is that all stations include a monthly time series of good quality over the considered period.

\subsection{Methodology}

In this study we have subdivided Chad into three zones according to the climate of the ground station. Therefore, the northern zone is composed of one station, the central zone of 3 stations and the zone south zone of 3 stations. For each zone, we average the data of different stations to obtain a data by climate zone. In addition, the data representing the whole country are calculated with the average from the 3 climate zones. Anomalies calculations (over the considered period) have been performed on all parameters except for precipitation for which it is rather the Standardized precipitation index SPI is used (McKee et al., 1993; 1995) [24] [25].

\section{Results and Discussion}

\subsection{Annual and Seasonal Characterization of Sunshine Duration}

We begin by shown in the Figure 2, the annual distribution of sunshine duration from 1950 to 2010 in Chad. Figures 2(a)-(d) represent respectively the north, center, south and for the whole country (Chad). The north of Chad (Figure 2(a)) represented by the Faya-largeau station which is located in the desert is characterized by a strong annual sunshine with an annual average around (3612.33 hrs/year). Indeed, this region is one of the sunniest areas in the world. From 1970 to 1975 during the great drought of Sahel, the sunshine in this part of
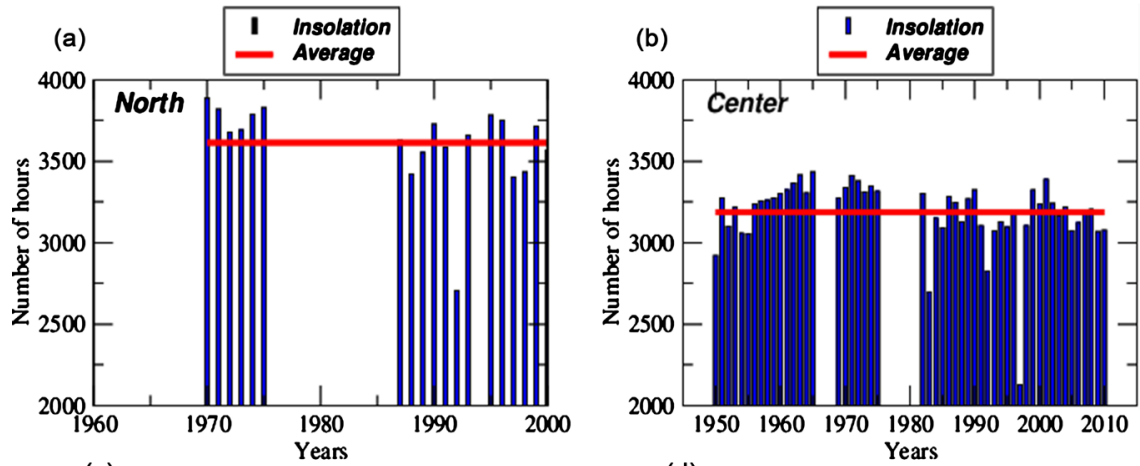

(c)

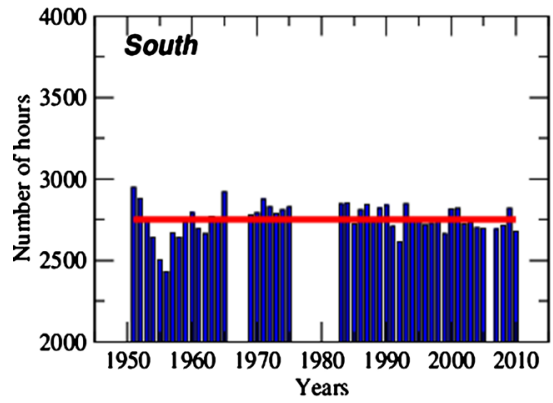

(d)

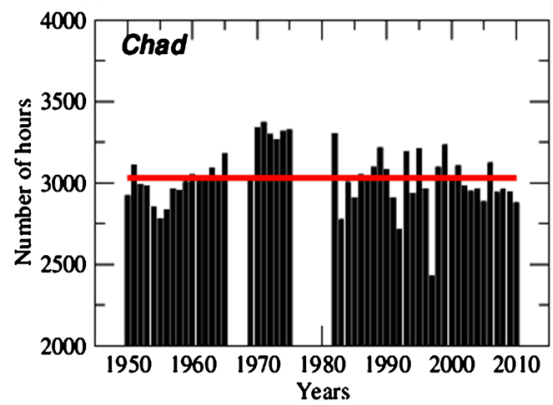

Figure 2. Annual distribution of sunstroke duration in North, Central, Southern Chad and Chad from 1950-2010. 
the country is above the annual average avec peaked around $3889.28 \mathrm{~h}$ /year for the year 1970. Then it decreases gradually from 1987 to 1992 and increases slightly in 1993, 1995, 1996 and 1999. However, the years 1988 and 1992 are the least sunniest in the series with values lower than $2703.17 \mathrm{hrs} /$ year especially in 1992. The center (Figure 2(b)) composed by Abeche, N'Djamena and Amti-man stations, is characterized by strong insolation during the dry years (from 1960 to 1975) higher than average. From 1983, there is a slight decrease until 2000 and a gradual increase between 2001 and 2005 and finally another decline from 2010. This Sahelo-Sudanian zone received more than $3411.94 \mathrm{hrs} /$ year of sunshine in 1971 (dry year). However, we note that in 1983, a decreasing trend values lower than $2125.48 \mathrm{hrs} /$ year in 1997. In the south of the country (Figure 2(c)), sunshine is significant between the years 1951 and 1984 (above average) with a maximum of $2947.38 \mathrm{hrs} /$ year in 1951. It varies around the average between 1954 and 1958. However, the minimum in insolation ( $2430.85 \mathrm{hrs} /$ year) is noted in 1958 during the wet years. The Chad sunshine average is represented in Figure 2(d)). There is an insolation greater than $3030.91 \mathrm{hrs} /$ year from 1959 to 1975, with a maximum of $3369.44 \mathrm{hrs} /$ year in 1971. However, the downward trend starts in 1992 up to 1997 with values of around $2427.64 \mathrm{hrs} /$ year.

Figure 3 illustrates the monthly distribution of sunshine duration between 1950 to 2010 in hour per day respectively in the north (Figure 3(a)), center (Figure 3(b)), south (Figure 3(c)) and an average over Chad country (Figure $3(\mathrm{~d})$ ). In the north of the country, the sunshine duration is about $10 \mathrm{~h} /$ day each month. We note an homogeneous monthly distribution in all seasons. However, the minima are noted in march and september with values lower than $9.3 \mathrm{~h} /$ day.
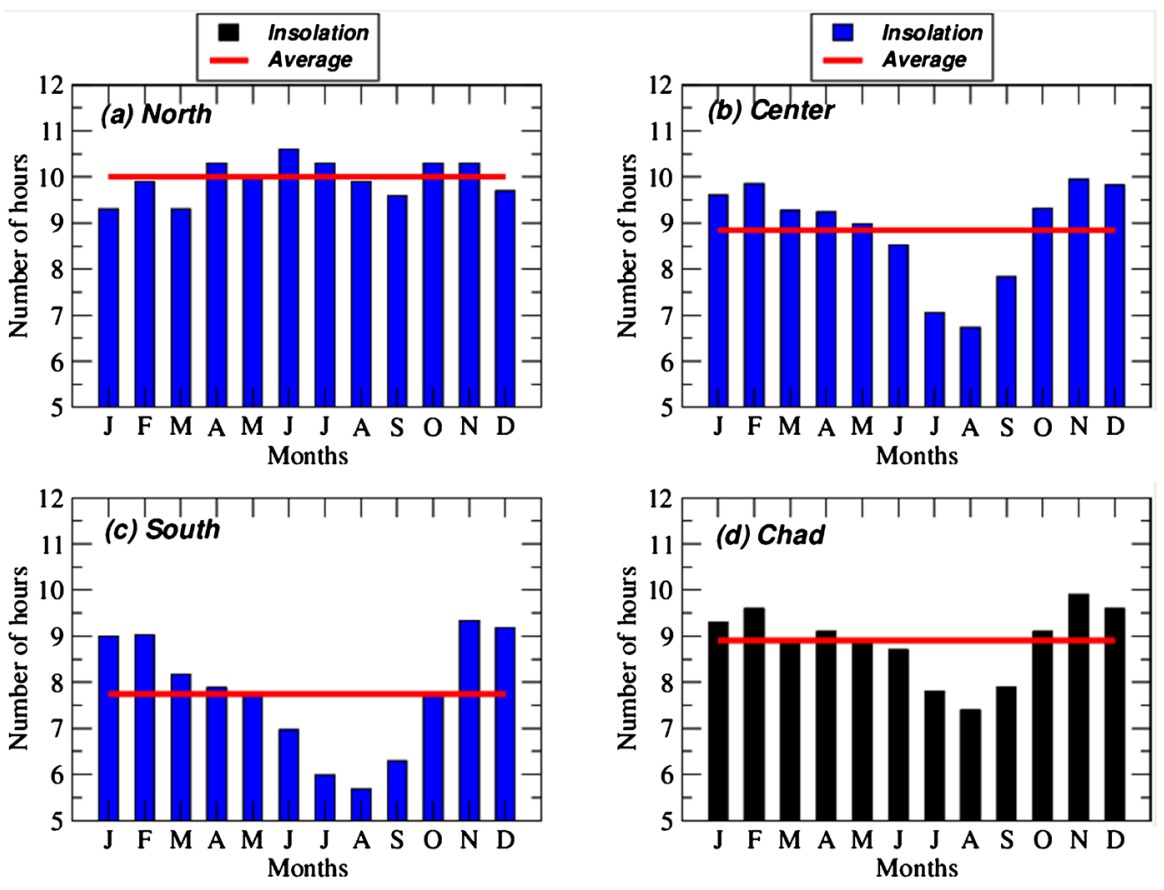

Figure 3. Monthly distribution of the duration of insolation in North, Central and South of Chad and in Chad from 1950 to 2010. 
Unlike the north, the sunshine duration in the center the country follows a very marked seasonality. The maxima are noted during the dry season between October and May exceeding $9.85 \mathrm{~h}$ /day and the minima in the rainy season between June and September. The minimum is recorded in the month of August with values lower than $6.73 \mathrm{~h} /$ day. Moreover, there is a marked seasonality of sunshine duration in the south with maxima (exceeding $9 \mathrm{~h}$ /day) in the dry season and minima in the rainy season (values lower than $5.68 \mathrm{~h} /$ day) in August). Figure 3(d) summarizes the monthly distribution of sunshine over Chad from 1950 to 2010. It shows a marked seasonality of sunshine distribution with maxima during the dry season (from October to May) and minima in the rainy season from June to September. The peak is recorded in November and February with values around $9 \mathrm{~h}$ /day while the minima are noted during the rainy season in July and August with values less than $7.4 \mathrm{~h} /$ day.

Table 1 summarizes the annual and monthly of sunshine duration on the different parts of the country and an average over the whole country. The table is revealing a strong gradient between the north and the south.

To better highlight the different periods in terms of variability of sunshine at Chad, we represent in the Figure 4 the annual anomaly of insolation duration

Table 1. Annual and Monthly Insolation in North-Central-South of Chad and Chad.

\begin{tabular}{ccccc}
\hline Insolation & Chad & North & Center & South \\
\hline $\begin{array}{c}\text { Average annual } \\
\text { Insolation (hrs/year) }\end{array}$ & $3030.91 \pm 176.33$ & $3612.33 \pm 261.18$ & $3185.50 \pm 208.78$ & $2753.39 \pm 95.92$ \\
$\begin{array}{c}\text { Average monthly } \\
\text { Insolation (hrs/day) }\end{array}$ & $8.9 \pm 0.8$ & $10 \pm 0.41$ & $8.85 \pm 1.1$ & $7.75 \pm 1.28$ \\
\hline
\end{tabular}
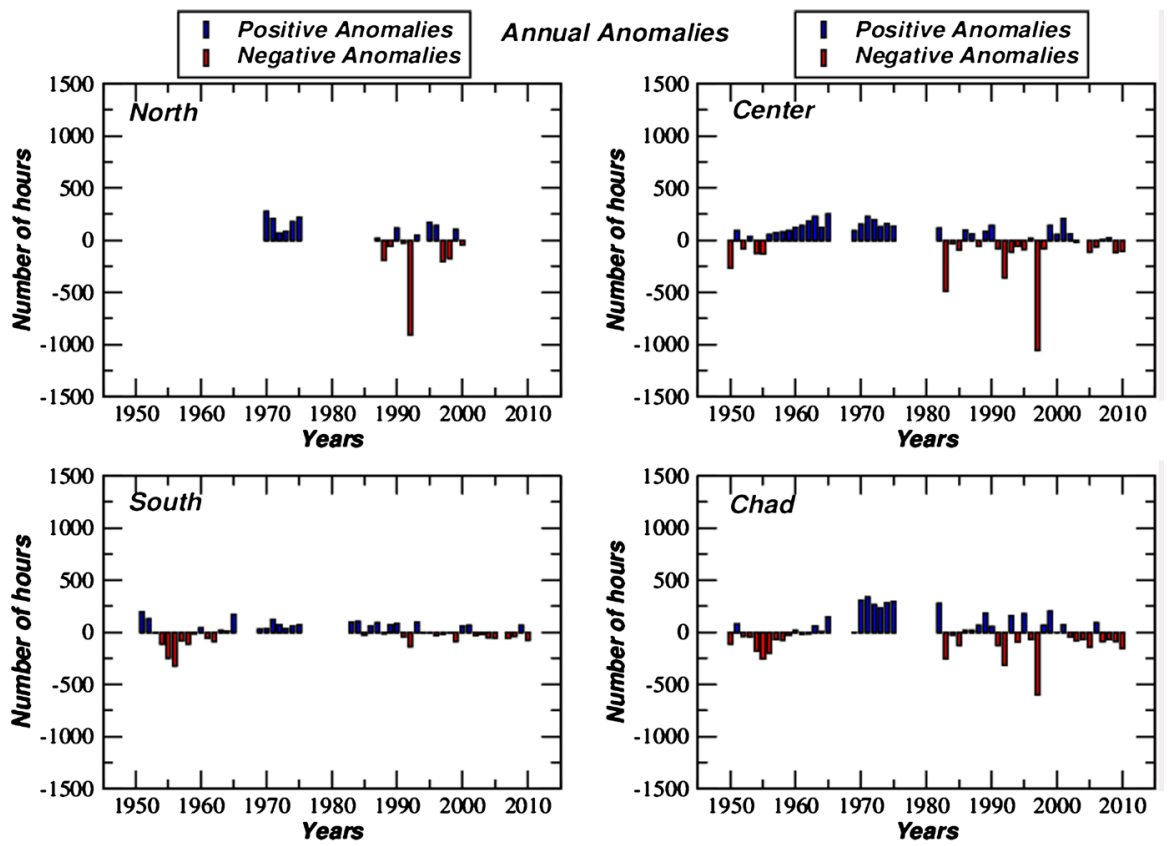

Figure 4. Trend of the anomalies of the duration of sunshine between 1950 to 2010 in North, Central, and South of Chad and in Chad. 
from 1950 to 2010. Figures 4(a)-(d) represent respectively the annual anomaly in the north, center, and south and for the whole country (Chad). These figures clearly show a variability of sunshine depending of climatic periods in Sahel region. They show the existence of three major periods in terms of insolation. At, we record negative anomalies from 1950 to 1970 corresponding to the wet years in Chad and the Sahel. Then, the period from 1970 to 1990 corresponds to the great drought that occurred throughout the region. This period is manifested by positive anomalies in insolation all over Chad. And finally, the period from 1993 to 2010 called the return period of the rainfall is characterized by a very marked annual variability of sunshine duration. During this period, the positive and negative anomalies succeeding from year to year.

Table 2 summarizes the insolation anomalies for each period and for the different regions of Chad. We note a north-south gradient and also the effect of the three climatic periods on sunshine duration. For instance, the anomaly goes from $-23.47 \mathrm{~h}$ /year during the humid period to $73.12 \mathrm{~h} /$ year during the great drought and to $-43.53 \mathrm{~h} /$ year for the return period.

\subsection{Effect of Seasonal Variability of Meteorological Parameter on Insolation Duration}

In order to assess the annual impact of meteorological parameters on sunshine duration, we begin by analyzing the Standardized precipitation index (SPI) in Chad from 1950 to 2010. Figure 5 presents annual anomalies of insolation (Figure 5(b)) and precipitation (SPI index in Figure 5(a)) from 1950 to 2010 over Chad. The SPI index (Figure 5(a)) showed that Chad experienced three major climatic periods in terms of precipitation. At first, Chad and the Sahel experienced a very wet period from 1950 to 1970 . This was manifested in Chad by positive SPI (see Figure 5(a)) from 1950 and 1970. Consequently, the sunshine duration was lower during this wet period with negative anomalies around -200 hrs year. Afterwards, the region has suffered an unprecedented drought during the period 1970-1990 (Ali and Lebel, 2009; Dai et al., 2004b) [26] [27]. This sudden decrease of rainfall has affected the entire Sahel region, making it the strongest climatic signal that the earth has received since meteorological measures exist (Dai et al., 2004b; Hubert \& Carbonnel, 1987; Hubert et al., 1989; [Giannini et al., 2008; [27] [28] [29] [30]. This dry period resulted by an increase of sunshine duration from 1970 to 1990. During this period, Chad earns more than 250 hours per year on average. The last two decades (from 1990 to 2010) are characterized by the more or less return of rains. Indeed, there is a very marked

Table 2. Annual North-Central-South Anomalies of Chad and Chad.

\begin{tabular}{ccccc}
\hline Periods & Chad (hrs/year) & North (hrs/year) & Center (hrs/year) & South (hrs/year) \\
\hline Wet & -23.47 & & -16.04 & -24.92 \\
Dried & 73.12 & 76.92 & $47: 72$ & 42.56 \\
Return & -41.53 & -85.45 & -87.13 & -12.63
\end{tabular}




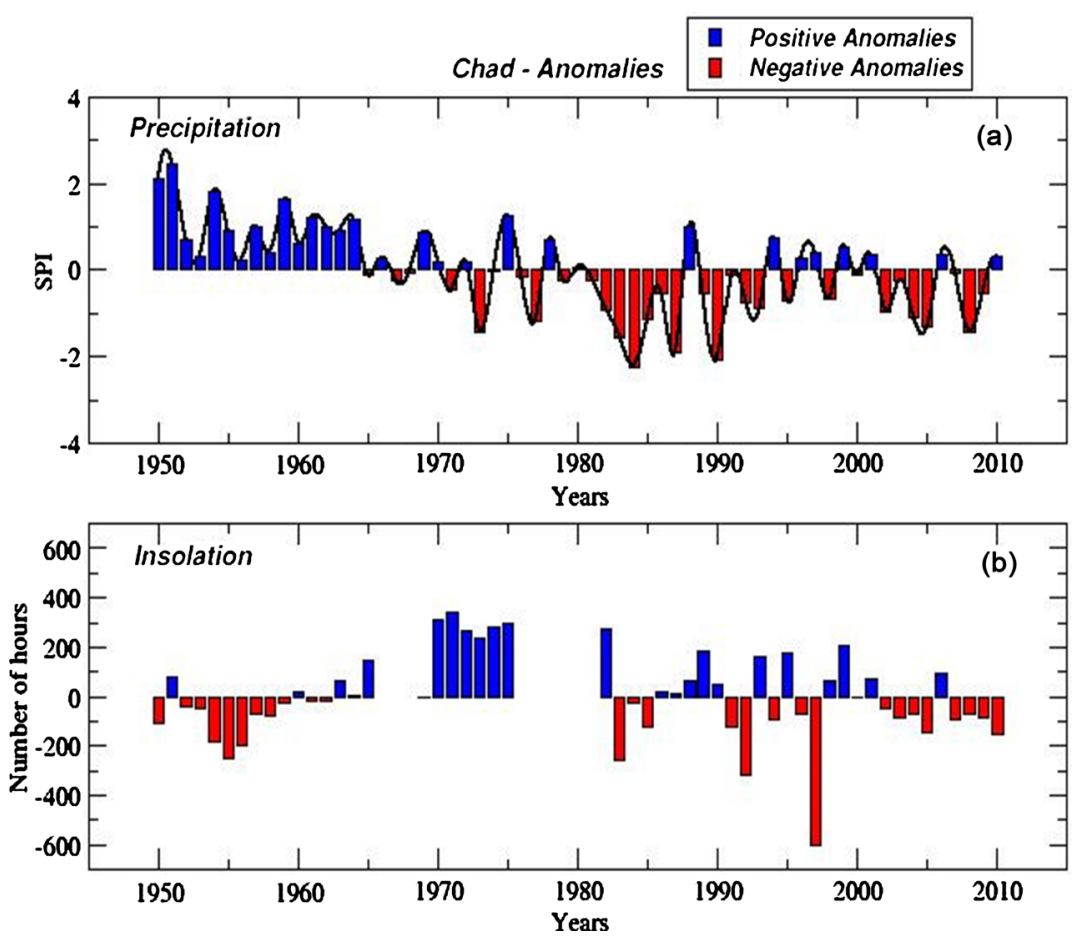

Figure 5. Trend in sunshine duration and precipitation anomalies between 1950 and 2010 in Chad.

interannual variability of SPI from year to year. Further, the sunshine duration varies from year to year during this period.

Figure 6 illustrates the anomalies of relative humidity, temperature means, temperature maximum and temperature minimum from 1950 and 2010 in Chad. We note that, the relative humidity follows the same trend as the sunshine duration. Indeed, insolation is a parameter that depends on relative humidity and therefore the cloud cover. We recognize the signature of the three major climatic periods of Chad. In fact, the positive anomalies of relative humidity (Figure 6(a)) are noted between 1950 and 1970. From 1970 to 1990, the relative humidity decreases by more than 5\% per year. And beyond the 1990s, there are fluctuating anomalies from year to year. However, temperatures (mean, maximum and minimum) do not follow the same trend with sunshine and precipitation (Figures 6(b)-(d)). Here, only two periods in terms of change are noted. The period from 1950 to 1990 is a period with negative anomalies. From the 1990 have noted a continued increase of temperatures in Chad. Thus, we can say that the increase of temperatures in Chad is not synonymous with an increase in the duration of insolation. In fact, the variability of temperatures in recent decades is mainly due to climate change on a global scale.

Table 3 summarizes the impact of these three periods of sunshine on the different meteorological parameters in Chad. Overall, the anomaly of relative humidity goes from 0.32 during the humid period to -1.39 during the great drought period and to 1.02 for the return period. Likewise, the anomaly of precipitations goes from 0.83 during the humid period to -0.56 during the great 

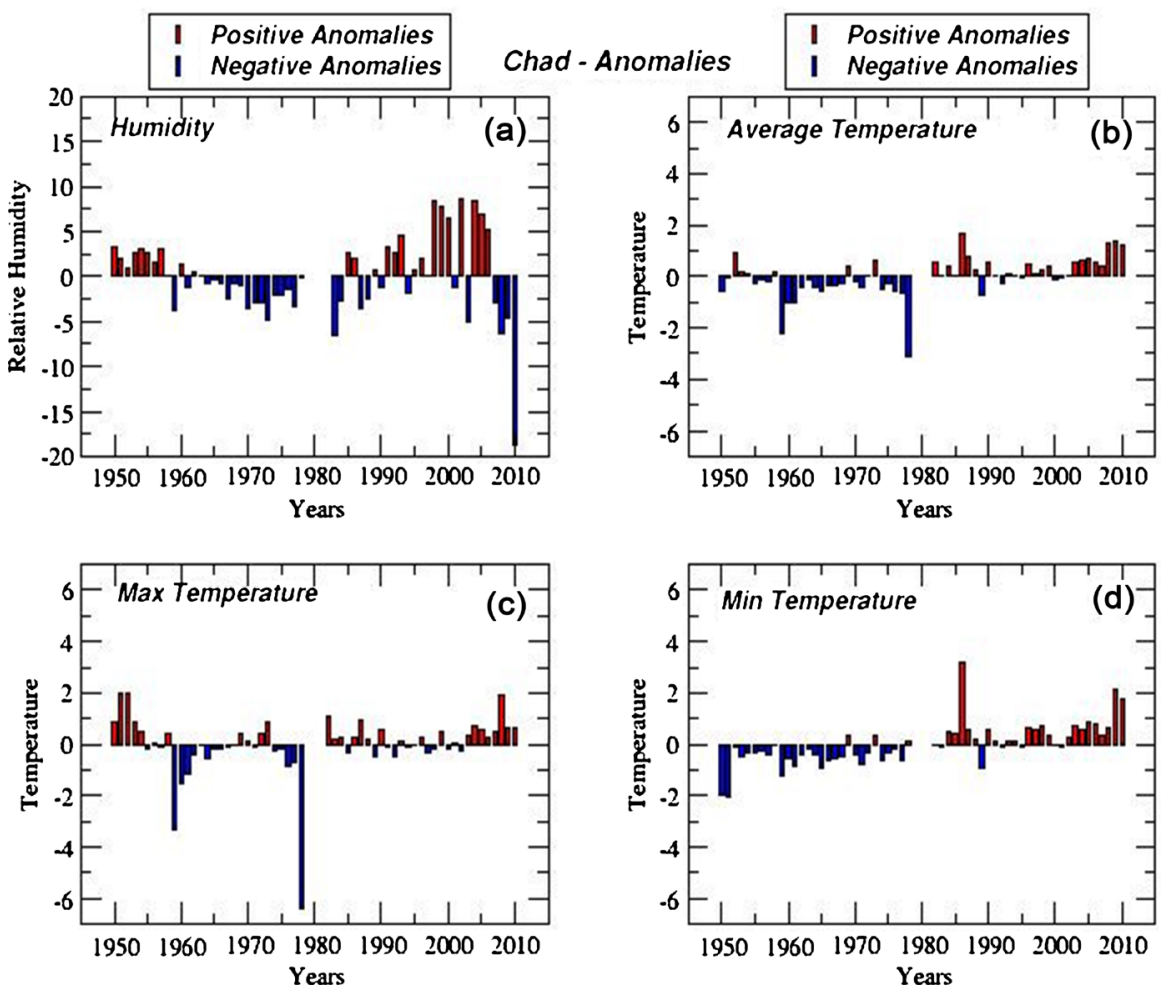

Figure 6. Trend of relative humidity temperature anomalies between 1950 and 2010 in Chad.

Table 3. Chad periods.

\begin{tabular}{cccccc}
\hline Periods & humidity & Temperature_Max & Temperature_Min & Temperature_Moy & Precipitation \\
\hline Wet & 0.32 & -0.02 & -0.6 & -0.3 & 0.83 \\
Dried & -1.39 & -0.22 & 0.1 & -0.09 & -0.56 \\
Return & 1.02 & 0.3 & 0.6 & 0.39 & -0.28 \\
\hline
\end{tabular}

drought period and to -0.28 for the return period. Between the wet and dry period, there is an increase for average and minimum temperatures; and a maximum temperature increase. These changes are probably due to climate variability at the regional scale. However, between the dry period and return, the temperatures increase considerably. These increases are due to global scale climate change and therefore does not have a strong impact on the duration of sunshine.

\section{Conclusions}

The objective of this study was to evaluate the long-term variability of insolation duration and its interaction with meteorological parameters such as surface temperature, precipitation and relative humidity in Chad from 1950 to 2010. On average Chad receives more than $3030.91 \pm 176.33$ hours per year. This corresponds to $8.9 \pm 0.8$ hours per day. Likewise, there is a strong gradient between the north and south of the country. For instance, the daily insolation is about 10 \pm 0.41 hours in the north, $8.85 \pm 1.1$ hours in the center and $7.75 \pm 1.8$ hours in 
the south of the country. Furthermore, there is a marked seasonality of sunshine duration with maximums in the dry season and minimums during the rainy season. The study of anomalies highlight three great periods in terms of duration of insolation. At first, there is the period where anomalies of insolation duration were negative (called humid period) between 1950 to1970. Indeed, during this period Chad and the whole Sahelian region were wet. From 1970 to 1990, the region suffered a severe drought which resulted in an increase in the duration of sunstroke in Chad. And finally, the period between 1990 to 2010 called return period is characterized by rapid fluctuations (from year to year) of the insolation duration. This work also showed that the duration of insolation had a direct relation with precipitations and relative humidity.

This shows the regional aspect of these three parameters which are: insolation duration, precipitations and relative humidity. However, the relationship between temperatures and sunstroke duration is not direct, especially during the period of return of the rains between 1990 and 2010. During this period, temperatures increase rapidly with the emergence of regular heat waves, mainly due to the global climatic changes.

\section{Acknowledgements}

Through this article, I would like to thank the people of Chad's Directorate General of Meteorology for providing me with these data. I wish to underline the excellent encouragement, techniques and review and recommendations provided by Ms. Sy (SOUKEYNA) for his contribution to the editorial audit in English.

\section{Conflicts of Interest}

The authors declare no conflicts of interest regarding the publication of this paper.

\section{References}

[1] Ranzi, R. and Rosso, R. (1995) Distributed Estimation of Incoming Direct Solar Radiation over a Drainage Basin. Journal of Hydrology, 166, 461-478. https://doi.org/10.1016/0022-1694(94)05099-J

[2] Pandey, V., Pandey, P.K. and Mahanta, A.P. (2014) Calibration and Performance Verification of Hargreaves-Samani Equation in a Humid Region. Irrigation and Drainage, 63, 659-667. https://doi.org/10.1002/ird.1874

[3] Pandey, P.K., Dabral, P.P. and Pandey, V. (2016) Evaluation of Reference Evapotranspiration Methods for the Northeastern Region of India. International Soil and Water Conservation Research, 4, 52-63. https://doi.org/10.1016/j.iswcr.2016.02.003

[4] Murthy, V.R.K. (2011) Crop Growth Modeling and Its Applications in Agricultural Meteorology. Satellite Remote Sensing and GIS Applications in Agricultural Meteorology, 1, 235-261.

[5] Wang, L., Gong, W., Ma, Y. and Zhang, M. (2013) Modeling Regional Vegetation NPP Variations and Their Relationships with Climatic Parameters in Wuhan, China. Earth Interact, 17, 1-20. https://doi.org/10.1175/2012EI000478.1

[6] Wang, H., Liu, D., Lin, H., Montenegro, A. and Zhu, X. (2015) NDVI and Vegeta- 
tion Phenology Dynamics under the Influence of Sunshine Duration on the Tibetan Plateau. International Journal of Climatology, 35, 687-698.

https://doi.org/10.1002/joc.4013

[7] Hassane Babikir, M., Njomo, D., Khayal, M.Y., Temene, H.D. and Joel, D.T. (2018) Estimation of Direct Solar Radiation of Chad. Energy and Power Engineering, 10, 212-225. https://doi.org/10.4236/epe.2018.105015

[8] Yang, Y.H., Zhao, N., Hao, X.H. and Li, C.Q. (2009) Decreasing Trend of Sunshine Hours and Related Driving Forces in North China. Theoretical and Applied Climatology, 97, 91-98. https://doi.org/10.1007/s00704-008-0049-x

[9] Lenuta, M., Marius-Victor, B., Roxana, B., Alexandru, D., Magdalena, M.D. and Ancuta, M. (2014) An Overview of Annual Climatic Changes in Romania: Trends in Air Temperature, Precipitation, Sunshine Hours, Cloud Cover, Relative Humidity and Wind Speed during the 1961-2013 Period. Carpathian Journal of Earth and Environmental Sciences, 9, 253-258.

[10] Dobesch, H. (1992) On the Variations of Sunshine Duration in Austria. Theoretical and Applied Climatology, 46, 33-38. https://doi.org/10.1007/BF00866445

[11] Sanchez-Lorenzo, A., Calbo, J. and Martin-Vide, J. (2008) Spatial and Temporal Trends in Sunshine Duration over Western Europe (1938-2004). Journal of Climate, 21, 6089-6098. https://doi.org/10.1175/2008JCLI2442.1

[12] Bedoum, A., Bouka Biona, C., Alladoum, B., Issak, A. and Laohoté B. (2013) Variabilités climatiques et ruptures dans les séries des précipitations en République du Tchad. Revue Ivoirienne des Sciences et Technologie, 21-22, 187-208.

[13] Pyarimohan, M., Ahmat Younous, A.-L. and Kanhu Charan, P. (2018) Observed Climate Variability over Chad Using Multiple Observational and Reanalysis Datasets. Global and Planetary Change, 162, 252-265. https://doi.org/10.1016/j.gloplacha.2018.01.013

[14] Lebel, T., Amani, A., Cazenave, F., Lecocq, J., Taupin, J.D., Elguero, E., Greard, M., Le Barbe, L., Laurent, H., D’Amato, N. and Robin, J. (1996) La distribution spatio-temporelle des pluies au Sahel: Apport de l'expérience EPSAT-Niger, Mélanges à la mémoire de Jean Rodier. Publication AISH No. 238, 77-98.

[15] Lebel, T. and Ali, A. (2009) Recent Trends in the Central and Western Sahel Rainfall Regime (1990-2007). Journal of Hydrology, 375, 52-64.

https://doi.org/10.1016/j.jhydrol.2008.11.030

[16] Nicholson, S.E. (1998) Interannual and Interdecadal Climate Variability of Rainfall over African Continent during the Last Two Centuries. In: Servat, E., Hugues, D., Fritsch, J.M. and Hulme, M., Eds., Water Resources Variability in Africa during the XXth Country, ORSTOM/AISH/UNESCO, No. 252, 107-116.

[17] Nicholson, S.E., Some, B. and Kone, B. (2000) An Analysis of Recent Year Analysis of Rainfall Conditions in West Africa, Including the Rainy Seasons of the $1997 \mathrm{El}$ Niňo and the 1998 Niňa Years. Journal of Climate, 13, 2628-2640. https://doi.org/10.1175/1520-0442(2000)013<2628:AAORRC>2.0.CO;2

[18] Nicholson, S.E. (2000) Land Surface Processes and Sahel Climate. Review of Geophysics, 38, 117-139. https://doi.org/10.1029/1999RG900014

[19] Bigot, S., Moron, V., Melice, J.-L., Servat, E. and Paturel, J.E. (1998) Fluctuations pluviométriques et analyse fréquentielle de la pluviosité en Afrique centrale. In: Servat, E., Hugues, D., Fritsch, J.M. and Hulme, M., Eds., Water Resources Variability in Africa during the XXth Country, ORSTOM/AISH/UNESCO, No. 252, 71-78.

[20] Mahe, G., L'Hote, Y., Olivry, J.C. and Wotling, G. (2001) Trends and Discontinuities in the Regional Rainfall of West and Central Africa 1951-1989. Hydrological 
Sciences Journal, 46, 211-226.

https://doi.org/10.1080/02626660109492817

[21] Malhy, Y. and Wright, J. (2004) Spatial Patterns and Recent Trends in the Climate of Tropical Rainforest Regions. Philosophical Transactions of the Royal Society $B$, 359, 311-329. https://doi.org/10.1098/rstb.2003.1433

[22] Guenang, G.M. and Mkankam Kamga, F. (2012) Onset, Retreat and Length of the Rainy Season over Cameroon. Atmospheric Science Letters, 13, 120-127. https://doi.org/10.1002/asl.371

[23] Redelsperger, J. (2002) Le Livre Blanc. http://amma.mediasfrance.org/france/index

[24] McKee, T.B., Doesken, N.J. and Kleist, J. (1993) The Relationship of Drought Frequency and Duration to Time Scale. Proceedings of the 8 th Conference on Applied Climatology, American Meteorological Society, Anaheim, 17-22 January 1993, 179-184.

[25] McKee, T.B., Doesken, N.J. and Kleist, J. (1995) Drought Monitoring with Multiple Time Scales. Proceedings of the 9 th Conference one Applied Climatology, American Meteorological Society, Dallas, 15-20 January 1995, 233-236.

[26] Ali, A. and Lebel, T. (2009) The Sahelian Standardized Rainfall Index Revisited. International Journal of Climatolology, 29, 1705-1714. https://doi.org/10.1002/joc.1832

[27] Dai, A., Trenberth, K.E. and Qian, T. (2004) A Global Dataset of Palmer Drought Severity Index for 1870-2002: Relationship with Soil Moisture and Effects of Surface Warming. Journal of Hydrometeorology, 5, 1117-1130. https://doi.org/10.1175/JHM-386.1

[28] Hubert, P. and Carbonnel, P. (1987) Approche statistique de l'aridification de l'Afrique de l'Ouest. Journal of Hydrology, 95, 165-183.

https://doi.org/10.1016/0022-1694(87)90123-5

[29] Hubert, P., Carbonnel, J.P. and Chaouche, A. (1989) Segmentation des séries hydrométéorologiques: Application à des séries de précipitations et de débits de l'Afrique de l'ouest. Journal of Hydrology, 10, 349-367. https://doi.org/10.1016/0022-1694(89)90197-2

[30] Giannini, A., Biasutti, M., Held, I.M. and Sobel, A.H. (2008) A Global Perspective on African Climate. Climatic Change, 90, 359-383.

https://doi.org/10.1007/s10584-008-9396-y 